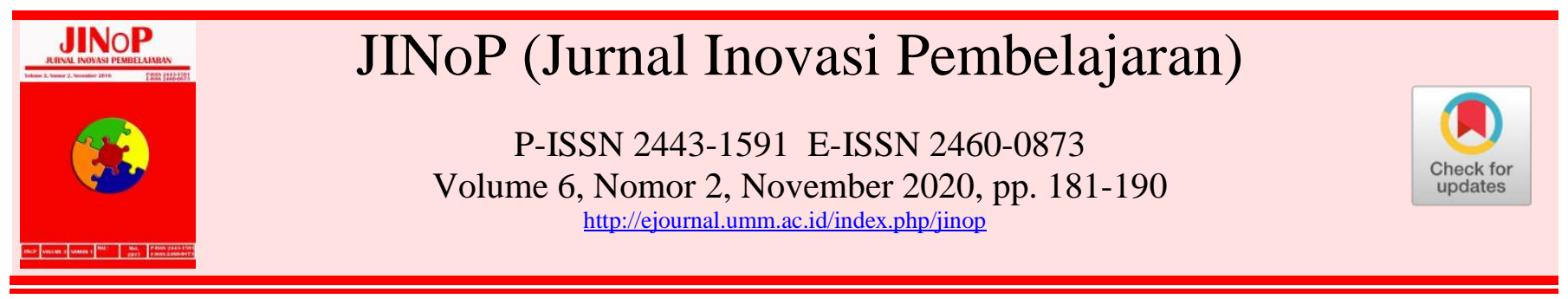

\title{
Pengembangan media board game untuk pembelajaran tematik di sekolah dasar
}

\author{
Wahyu Candra Dwi Safitri ${ }^{1 *}$ \\ ${ }^{1}$ Program Studi Pendidikan Guru Sekolah Dasar, Fakultas Keguruan dan Ilmu Pendidikan, \\ Universitas Kristen Satya Wacana, J1. Diponegoro No. 52-60, Salatiga, Indonesia \\ wahyucandrads@gmail.com* \\ *Penulis Koresponden
}

\begin{abstract}
ABSTRAK
Pembelajaran tematik di sekolah dasar sangat penting untuk memperkuat karakter siswa, salah satunya dengan media board game. Penelitian ini bertujuan untuk mengembangkan dan menguji kevalidan, kepraktisan, dan keefektifan media board game pada pembelajaran tematik di sekolah dasar. Metode penelitian yang digunakan adalah R\&D dengan desain ADDIE yang meliputi lima tahap, yakni 1) analysis (analisis), 2) design (perancangan), 3) development (pengembangan), 4) implementation (implementasi), dan 5) evaluation (evaluasi). Kevalidan produk diperoleh melalui uji pakar dengan instrumen validasi pakar. Kepraktisan produk diperoleh melalui uji coba terbatas 8 siswa dan pemberian angket untuk melihat respon siswa setelah menggunakan media board game. Keefektifan produk diperoleh melalui uji coba satu kelas dengan one grup pre-test-post-test design yang hasilnya diuji menggunakan Paired Sample t-test dengan SPSS 20.0. Hasil penelitian menunjukkan bahwa media board game dapat meningkatkan kemampuan pemecahan masalah pada pembelajaran tematik di sekolah dasar. Media pembelajaran dinyatakan valid berdasarkan hasil uji pakar media, pakar materi, dan pakar pembelajaran yang rata-ratanya mencapai $74.3 \%$ (tinggi). Media pembelajaran dinyatakan praktis berdasarkan hasil angket respon siswa mencapai 94\% (praktis). Media pembelajaran juga dinyatakan efektif berdasarkan rata-rata hasil pretes dan postes serta uji Paired Sample t-test pretest-post-test dengan menunjukkan nilai Sig. (2-tailed) sama dengan 0,000.
\end{abstract}

Kata Kunci: Board Game; Media Pembelajaran; Pemecahan Masalah; Siswa Sekolah Dasar.

\section{ABSTRACT}

This study aimed to develop and test the validity, practicality, and effectiveness of game board media on thematic learning in elementary schools. It employed Research and Development (R\&D) method with ADDIE design, including: 1) analysis, 2) design, 3) development, 4) implementation, and 5) evaluation. The product validity was obtained through expert tests using expert validation instruments. The product practicality was verified after limited trials to 8 students. Questionnaires were given to see student responses after using the game board media. The product effectiveness was validated by a one-class trial with one group pre-test-post-test design, tested using Paired Sample t-test in SPSS 20.0. Results showed that board game media improved elementary school students' problem-solving skills in thematic learning. The learning media is valid based on the test results of media experts, material experts, and learning experts. It is also practical based on the results of the student response questionnaire. The learning media is effective based on the results of the average pre-test and post-test and the Paired Sample t-test pre-test-post-test test results by showing the Sig. (2-tailed) equal to 0,000.

Keywords: Board Game; Learning Media; Primary School Students; Problem Solving.

diunggah: 2019-04-13, direvisi: 2020-10-23, diterima: 2020-11-20, dipublikasi: 2020-11-20

Copyright (c) 2020 Safitri, W.

This is an open access article under the CC-BY license

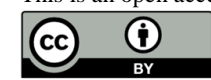


Cara sitasi: Safitri, W. (2020). Pengembangan media board game untuk pembelajaran tematik di Sekolah Dasar. JINoP (Jurnal Inovasi Pembelajaran), 6(2). 181-190. https://doi.org/10.22219/jinop.v6i2.8186

\section{PENDAHULUAN}

Kemampuan pemecahan masalah merupakan salah satu kemampuan yang ditekankan pada Kurikulum 2013 yang berbasis tema. Salah satu karakteristik pembelajaran tematik adalah menyajikan konsep dari berbagai mata pelajaran dalam suatu proses pembelajaran agar siswa mampu memahami konsep secara utuh dan untuk membantu siswa dalam memecahkan masalah yang dihadapi dalam kehidupan sehari-hari (Prastowo, 2015). Kemampuan pemecahan masalah memegang peranan agar siswa memiliki kemampuan berpikir, bernalar, memprediksi, dan mencari solusi dari masalah yang diberikan. Hal ini sejalan dengan tuntutan abad 21 yang mengharapkan pembelajaran dilakukan secara aktif, kreatif, inovatif dan mandiri melalui pemberian tantangan kepada siswa untuk dapat memecahkan permasalahan dalam kehidupan yang semakin kompleks dengan penggunaan teknologi yang ada dan melalui penggunaan prinsip-prinsip belajar yang berorientasi pada proyek dan permasalahan sampai aktivitas kolaboratif, sehingga dapat menghasilkan sumber daya manusia yang berkualitas dalam menghadapi berbagai tantangan dan tuntutan yang bersifat kompetitif (Rusman, 2017).

Kemampuan pemecahan masalah dapat dipelajari dari usia sekolah dasar. Satuan pendidikan sebagai wadah untuk mengembangkan kemampuan siswa hendaknya melaksanakan proses pembelajaran secara interaktif, inspiratif, menyenangkan, menantang, memotivasi siswa untuk berpartisipasi aktif, serta memberikan ruang yang cukup bagi prakarsa, kreativitas, dan kemandirian sesuai dengan bakat, minat, dan perkembangan fisik serta psikologis siswa (Kemendikbud, 2016). Salah satu faktor yang memengaruhi keberhasilan suatu kegiatan pembelajaran pada satuan pendidikan adalah model penyajian materi. Model penyajian materi yang menyenangkan, tidak membosankan, menarik, dan mudah dimengerti oleh siswa memiliki pengaruh yang positif terhadap proses pembelajaran (Susanto, 2016).

Model penyajian materi yang menyenangkan dan menarik dapat diterapkan melalui penggunaan media pembelajaran. Media pembelajaran yang melibatkan aktivitas bermain tentunya dapat menciptakan suasana belajar yang menyenangkan. Permainan dalam sebuah pembelajaran memberikan kesan bahwa belajar itu menyenangkan (learning is fun), sehingga siswa tidak tertekan secara psikologis dan tidak merasa bosan terhadap apa yang diajarkan oleh guru. Anak ketika melakukan permainan akan berusaha untuk memiliki keinginan dan mencapai keinginannya, sehingga semua aspek perkembangan anak dapat ditingkatkan, dan dengan kebebasan anak dapat berekspresi serta bereksplorasi untuk memperkuat hal-hal yang sudah diketahui maupun menemukan hal-hal baru (Trinova, 2012). Selain itu, kegiatan bermain memberikan dampak yang baik bagi anak. Dampak kegiatan bermain yang timbul antara lain anak dapat belajar mengambil keputusan, menentukan, mencipta, membongkar, memasangkan, mencoba, mengembalikan, mengeluarkan pendapat dan memecahkan masalah, mengerjakan sesuatu secara tuntas, bekerja sama dengan teman dan mengalami berbagai macam perasaan (Kustiawan, 2016).

Realitanya, media pembelajaran yang ada hanya menitikberatkan pada hasil belajar. Berbeda dengan media pembelajaran yang dikembangkan peneliti yang 
merujuk kepada kemampuan berpikir tingkat tinggi (HOTS), sehingga siswa tidak hanya mengingat berdasarkan hafalan. Selain itu, media board game ditujukan untuk siswa kelas rendah agar mampu bersaing dan bekerja sama secara tidak langsung melalui sebuah permainan.

\section{METODE}

Penelitian ini merupakan jenis penelitian R\&D dengan model pengembangan ADDIE yang terdiri dari lima tahap yakni 1) analysis (analisis), 2) design (perancangan), 3) development (pengembangan), 4) implementation (implementasi), dan 5) evaluation (evaluasi).

Secara jelas, tahapan model ADDIE dapat dilihat pada gambar 1 berikut:

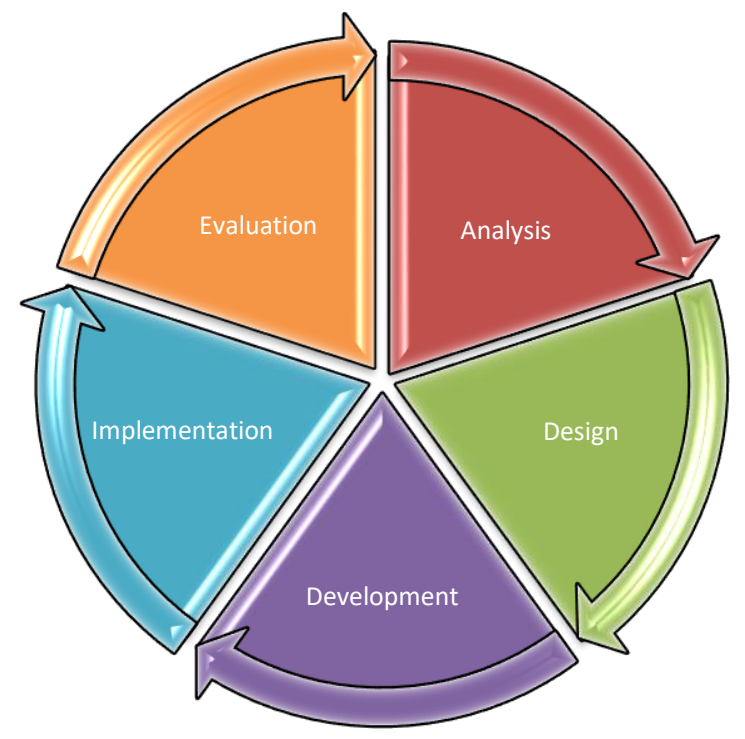

Gambar 1. Model Pengembangan ADDIE

Berdasarkan tahap-tahap model pengembangan ADDIE secara rinci dapat dijelaskan berikut ini:

\section{Analysis (Analisis)}

Analisis dilakukan dengan wawancara guru untuk mengetahui pengimplementasian Kurikulum 2013 di SD, serta menganalisis angket untuk mengetahui kemampuan awal siswa dalam menggunakan media pembelajaran yang berkaitan dengan aktivitas bermain dan materi tematik. Selain itu, peneliti juga melakukan wawancara dengan siswa untuk menganalisis kebutuhan siswa mengenai kemampuan pemecahan masalah.

Subjek dalam penelitian ini adalah guru dan siswa kelas III SD Negeri 6 Sendangharjo, Kecamatan Karangrayung, Kabupaten Grobogan.

\section{Design (perancangan)}

Design (perancangan) dilakukan dengan langkah pertama yaitu menetapkan judul media pembelajaran. Langkah selanjutnya menyiapkan buku-buku sumber, melakukan identifikasi terhadap kompetensi dasar, serta merancang bentuk kegiatan pembelajaran yang sesuai. Setelah itu melakukan identifikasi terhadap indikator pencapaian kompetensi, serta merancang bentuk dan jenis penilaian yang akan disajikan. Kemudian dilanjutkan dengan merancang media pembelajaran dan penyusunan rencana pelaksanaan pembelajaran. 


\section{Development (pengembangan)}

Development (pengembangan) dilakukan untuk mengetahui kevalidan produk melalui uji pakar meliputi pakar materi, pakar media, dan pakar pembelajaran. Setelah mendapatkan kritik dan masukan dari validator, dilakukan revisi sesuai dengan saran pakar. Hal ini dilakukan sebelum uji coba lapangan.

\section{Implementation (implementasi)}

Sebelum diujicobakan di lapangan, media diujicobakan kepada 5-8 siswa bersama guru untuk mengetahui kepraktisan media melalui instrumen angket. Setelah itu media diujicobakan pada satu kelas yang digunakan untuk penelitian. Pada tahap ini, hasil penilaian kemampuan pemecahan masalah pre-test dan posttest serta penilaian presentasi akan dianalisis untuk menentukan keefektifan media pembelajaran.

\section{Evaluation (evaluasi)}

Tahap ini dilakukan melalui pengolahan data pre-test dan post-test kemampuan pemecahan masalah menggunakan SPSS 20.0 for windows untuk dilakukan uji Paired Sample t-test.

\section{Teknik Analisis Data}

Data hasil validasi produk oleh pakar dianalisis menggunakan teknik deskriptif persentase dan kategoris untuk menggambarkan kelayakan media. Skor hasil pengukuran dengan menggunakan angket tertutup, kemudian dipersentasekan dengan menggunakan rumus:

$$
\mathrm{AP}=\frac{\text { Skor Aktual }}{\text { Skor Ideal }} \times 100 \%
$$

Keterangan

AP $\quad=\quad$ Angka Persentase

Skor Aktual $=$ Skor yang diberikan validator

Skor Ideal $=$ Skor maksimal hasil kali antara jumlah item dengan skor maksimal masing-masing item

Angka persentase kemudian dikelompokkan menjadi lima kategori sebagai berikut.

Tabel 1. Kategori angka presentase

\begin{tabular}{lll}
\hline \multicolumn{1}{c}{ Interval } & Kategori \\
\hline $81-100 \%$ & Sangat tinggi & \\
$61-80 \%$ & Tinggi & \\
$31-60 \%$ & Cukup & \\
$21-40 \%$ & Rendah & \\
$1-20 \%$ & Sangat rendah & \\
\hline
\end{tabular}

Berdasarkan kategori persentase di atas, maka media board game dinyatakan layak untuk diujicobakan apabila angka persentasi minimal mencapai kategori tinggi $(\geq 61 \%)$. Kepraktisan dilakukan dengan analisis hasil respon siswa ketika uji coba terbatas media board game. Keefektifan dilakukan dengan analisis komparatif, yakni membandingkan hasil pembelajaran sebelum dan sesudah penerapan media board game untuk satu kelas dengan one grup design pre-testpost-test menggunakan kriteria kemampuan pemecahan masalah meliputi aspek memahami masalah, merencanakan penyelesaian, melaksanakan penyelesaian, dan memeriksa kembali. Hasil dari ketiga kriteria digunakan untuk menentukan skor 
akhir. Skor akhir sebelum dan sesudah penerapan media dibandingkan dengan uji T sampel berpasangan (Paired Sample t-Test) melalui SPSS 20.0 for windows.

\section{HASIL DAN PEMBAHASAN Hasil}

Penelitian dan pengembangan produk ini dilakukan dengan model ADDIE. Berikut ini hasil penelitian berdasarkan lima tahap dalam model ADDIE.

Analysis (analisis)

Berdasarkan hasil wawancara dengan guru kelas III diperoleh data bahwa selama pembelajaran guru belum pernah mengembangkan media pembelajaran. Guru hanya sebatas menggunakan metode, media dan sumber belajar yang bervariasi. Salah satu contoh media yang digunakan oleh guru adalah power point. Hal ini menunjukkan bahwa belum ada media pembelajaran yang berkaitan dengan aktivitas bermain.

Peneliti juga menyebar angket tentang kemampuan awal siswa dalam menggunakan board game. Hal ini dilakukan guna mengetahui pengalaman siswa dalam bermain yang sesuai dengan media pembelajaran yang akan dikembangkan oleh peneliti. Hasil angket menunjukkan bahwa 30 siswa mengenal board game dan mengetahui aturan permainannya. Selain itu, peneliti melakukan identifikasi kemampuan awal siswa dalam materi pembelajaran tematik. Tema yang digunakan untuk mengidentifikasi kemampuan awal siswa adalah materi pada Tema 4 Tema 4 Kewajiban dan Hakku Subtema 3 Kewajiban dan Hakku dalam Bertetangga. Berdasarkan hasil angket yang diberikan peneliti, diketahui bahwa siswa Kelas III yang berjumlah 30 orang sudah mengenal ungkapan saran, dua bilangan cacah yang hasilnya diketahui, dan unsur-unsur karya dekoratif. Langkah selanjutnya yang dilakukan peneliti adalah wawancara dengan beberapa siswa. Berdasarkan hasil wawancara, siswa belum pernah mengerjakan soal dengan menuliskan langkahlangkah penyelesaian. Peneliti mencoba memberikan satu contoh soal cerita mengenai pemecahan masalah dan menanyakan kepada siswa mengenai perencanaan penyelesaian soal yang akan dilakukan, namun siswa kebingungan dan berbalik bertanya kepada peneliti.

\section{Design (perancangan)}

Langkah pertama dalam perancangan adalah menetapkan judul board game yakni Puzzle Tematik. Langkah selanjutnya menyiapkan buku-buku sumber seperti buku guru dan buku siswa dan referensi lainnya dari internet, melakukan identifikasi terhadap kompetensi dasar, serta merancang bentuk kegiatan pembelajaran yang sesuai. Setelah itu melakukan identifikasi terhadap indikator pencapaian kompetensi, serta merancang bentuk dan jenis penilaian yang akan disajikan. Kemudian dilanjutkan dengan merancang media board game dan penyusunan rencana pelaksanaan pembelajaran. Perancangan dilakukan dengan cara menyusun media board game menggunakan Corel Draw X7 untuk menghasilkan bentuk desain. Komponen media board game antara lain: 1 papan permainan, 16 kartu papan, 16 kartu soal, 16 kartu pilihan A, 16 kartu pilihan B, 16 kartu kunci A, 16 kartu kunci B, dan buku petunjuk (rulebook) yang dikemas dalam wadah yang praktis.

\section{Development (pengembangan)}

Media pembelajaran yang telah dirancang, kemudian diuji pakar meliputi pakar media pembelajaran, materi pembelajaran, dan pembelajaran. Hasil uji pakar secara rinci disajikan pada tabel 2 berikut. 
Tabel 2. Hasil uji pakar

\begin{tabular}{llllll}
\hline No & \multicolumn{1}{c}{ Indikator } & Skor Ideal & Skor Aktual & AP $(\boldsymbol{\%})$ & Kategori \\
\hline 1. & Media pembelajaran & 75 & 49 & $65 \%$ & Tinggi \\
2. & Materi pembelajaran & 60 & 45 & $75 \%$ & Tinggi \\
3. & Pembelajaran & 60 & 50 & $83 \%$ & Sangat tinggi \\
\hline Rata-rata & & & $74.3 \%$ & Tinggi \\
\hline
\end{tabular}

Berdasarkan kriteria kelayakan media yang dikembangkan, media pembelajaran, materi pembelajaran, dan pembelajaran berada dalam kategori tinggi dan sangat tinggi (nilai persentase $\geq 61$ ), sehingga media layak digunakan.

\section{Implementation (implementasi)}

Langkah yang dilakukan pada tahap implementasi adalah analisis angket respon siswa dari hasil uji coba terbatas, hasil analisis data penilaian kemampuan pemecahan masalah masing-masing aspek pada saat pre-test dan post-test, serta hasil penilaian presentasi. Hasil analisis angket respon siswa disajikan pada tabel 3 berikut.

\section{Tabel 3. Hasil analisis angket respon siswa}

\begin{tabular}{|c|c|c|}
\hline No. & Pernyataan & Skor \\
\hline 1. & Saya tertarik belajar dengan menggunakan media Puzzle Tematik & 8 \\
\hline 2. & Saya senang dapat belajar dengan menggunakan media Puzzle Tematik & 8 \\
\hline 3. & Saya dapat menjelaskan tentang materi yang ada pada media & 8 \\
\hline 4. & Saya mendapat petunjuk penggunaan media & 8 \\
\hline 5. & $\begin{array}{l}\text { Permasalahan yang ada pada media sering saya temukan di kehidupan sehari- } \\
\text { hari }\end{array}$ & 8 \\
\hline 6. & Saya dapat membaca tulisan yang ada pada media & 8 \\
\hline 7. & Dengan menggunakan media dapat menambah pengetahuan saya & 8 \\
\hline 8. & Saya dapat memahami bahasa yang ada pada media & 8 \\
\hline 9. & $\begin{array}{l}\text { Saya semakin bersemangat untuk belajar menyelesaikan soal dengan } \\
\text { pemecahan masalah }\end{array}$ & 6 \\
\hline 10. & $\begin{array}{l}\text { Setelah bermain, saya terbiasa menyelesaikan soal dengan pemecahan } \\
\text { masalah }\end{array}$ & 6 \\
\hline \multicolumn{2}{|r|}{ Jumlah } & 76 \\
\hline \multicolumn{2}{|r|}{ Persentase } & $95 \%$ \\
\hline
\end{tabular}

Tabel 4. Hasil data pemecahan masalah pada pre-test dan post-test

\begin{tabular}{lcccc}
\hline \multicolumn{1}{c}{ Aspek } & \multicolumn{2}{c}{ Pre-test } & \multicolumn{2}{c}{ Post-test } \\
\cline { 2 - 5 } & Skor & Persentase & Skor & Persentase \\
\hline $\begin{array}{l}\text { Memahami } \\
\text { masalah }\end{array}$ & 94 & $78 \%$ & 100 & $83 \%$ \\
$\begin{array}{l}\text { Merencanakan } \\
\text { penyelesaian }\end{array}$ & 58 & $48 \%$ & 98 & $82 \%$ \\
$\begin{array}{l}\text { Melaksanakan } \\
\text { penyelesaian }\end{array}$ & 101 & $84 \%$ & 103 & $86 \%$ \\
$\begin{array}{l}\text { Memeriksa } \\
\text { kembali }\end{array}$ & 26 & $22 \%$ & 92 & $77 \%$ \\
\hline
\end{tabular}

Berdasarkan hasil angket respon siswa uji terbatas diperoleh persentase 95\% siswa dapat menggunakan media board game, sehingga media dapat dikatakan praktis. Hasil data pemecahan masalah pada saat pre-test dan post-test dapat dilihat pada tabel 4 di atas. 
Hasil data pemecahan masalah pada pre-test menunjukkan bahwa pada dua aspek kemampuan pemecahan masalah memperoleh persentase kurang dari 50\%, yakni aspek merencanakan penyelesaian dengan persentase sebesar $48 \%$ dan aspek memeriksa kembali dengan persentase sebesar $22 \%$. Berbeda dengan hasil data pemecahan masalah pada post-test yang menunjukkan semua aspek kemampuan pemecahan masalah memperoleh persentase lebih dari 50\%. Hasil post-test menunjukkan bahwa aspek analisis masalah memperoleh persentase sebesar $83 \%$, aspek merencanakan penyelesaian dengan persentase sebesar 82\%, aspek melaksanakan penyelesaian dengan persentase sebesar $86 \%$, dan aspek memeriksa kembali dengan persentase sebesar $77 \%$. Hasil penilaian presentasi kemampuan pemecahan masalah secara rinci disajikan pada tabel 5 berikut.

Tabel 5. Hasil penilaian presentasi kemampuan pemecahan masalah

\begin{tabular}{cccc}
\hline Kategori & Interval & Frekuensi & Persentase \\
\hline Tinggi & $91-100$ & 3 & $10 \%$ \\
Sedang & $71-90$ & 22 & $73 \%$ \\
Rendah & $61-70$ & 5 & $17 \%$ \\
\hline & Jumlah & 30 & $100 \%$ \\
\hline
\end{tabular}

Berdasarkan hasil penilaian presentasi di atas, siswa dengan kemampuan presentasi kategori tinggi sebanyak 3 orang atau sebesar 10\%, yang masuk kategori sedang sebanyak 22 orang atau sebesar $73 \%$, dan yang masuk kategori rendah sebanyak 5 orang atau sebesar $17 \%$. Ilustrasi yang digunakan untuk memudahkan dalam memahami data penilaian presentasi disajikan dalam bentuk diagram sebagai berikut.

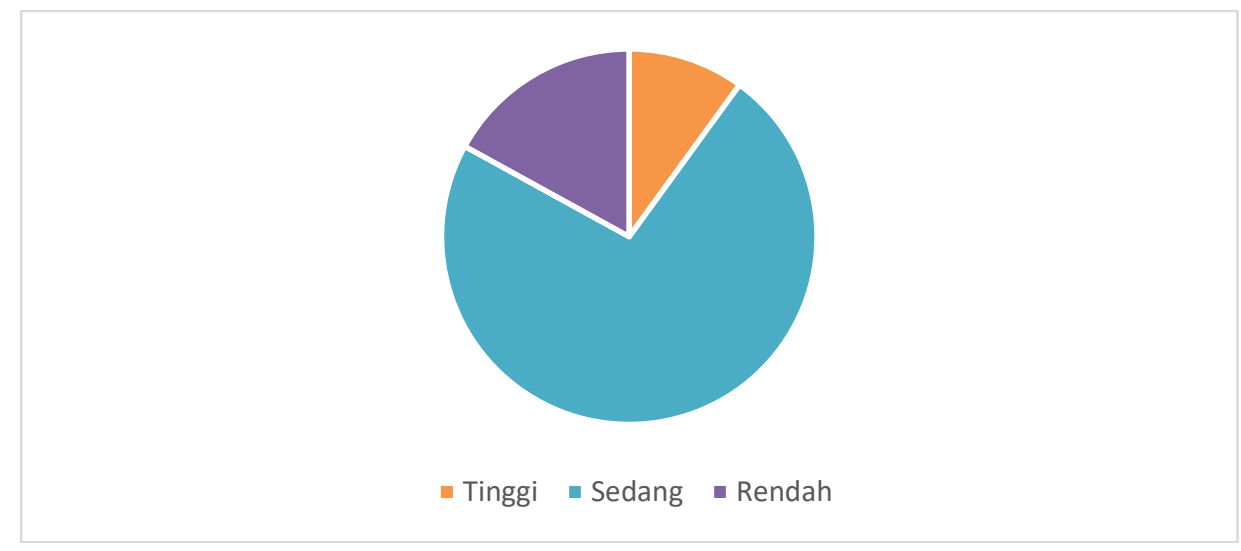

\section{Gambar 2. Diagram Lingkaran Hasil Penilaian Presentasi}

\section{Evaluation (Evaluasi)}

Langkah yang dilakukan pada tahap evaluasi adalah pengolahan data pretest dan post-test menggunakan SPSS 20.0 for windows untuk dilakukan uji Paired Sample t-test. Langkah yang dilakukan adalah Analyze-Compare means-Paired Sample t-test. Hasil uji disajikan pada tabel 6 sebagai berikut. 
Tabel 6. Hasil uji $t$

\begin{tabular}{|c|c|c|c|c|c|c|c|c|}
\hline & \multicolumn{5}{|c|}{ Paired Differences } & \multirow{3}{*}{$\mathrm{T}$} & \multirow{3}{*}{ Df } & \multirow{3}{*}{$\begin{array}{l}\text { Sig. (2- } \\
\text { tailed) }\end{array}$} \\
\hline & \multirow[t]{2}{*}{ Mean } & \multirow[t]{2}{*}{$\begin{array}{c}\text { Std. } \\
\text { Deviation }\end{array}$} & \multirow[t]{2}{*}{$\begin{array}{l}\text { Std. } \\
\text { Error } \\
\text { Mean }\end{array}$} & \multicolumn{2}{|c|}{$\begin{array}{l}95 \% \text { Confidence } \\
\text { Interval of the } \\
\text { Difference }\end{array}$} & & & \\
\hline & & & & Lower & Upper & & & \\
\hline $\begin{array}{ll}\text { Pair } & \text { pre-test }- \\
1 & \text { post-test }\end{array}$ & $-11,563$ & 3,465 & 633 & $-12,856$ & $-10,269$ & $18,276^{-}$ & 29 & , 000 \\
\hline
\end{tabular}

Hasil uji menunjukkan nilai Sig. (2-tailed) sama dengan 0,000 atau kurang dari 0,05 , sehingga dapat dikatakan bahwa terdapat perbedaan yang signifikan antara hasil belajar pada pre-test dan post-test.

\section{Pembahasan}

Berdasarkan hasil penelitian, media board game dapat meningkatkan kemampuan pemecahan masalah. Hal ini dikarenakan siswa memperoleh fasilitas belajar mengerjakan soal-soal melalui langkah-langkah pemecahan masalah. Hal ini sejalan dengan Polya (Wahyudi \& Anugraheni, 2017) yang menjelaskan bahwa terdapat empat langkah penyelesaian masalah, antara lain: 1) pemahaman masalah (understanding the problem), 2) perencanaan penyelesaian (devising a plan), 3) melaksanakan perencanaan (carrying out the plan), dan 4) pemeriksaan kembali proses dan hasil (looking back). Selain itu, Gagne (Susanto, 2016) menyatakan siswa yang memiliki kecakapan intelektual meliputi kemampuan membedakan, menguasai konsep dan prinsip, serta kemampuan pemecahan masalah merupakan siswa yang memiliki kemampuan berpikir tingkat tinggi.

Keberhasilan media board game untuk meningkatkan kemampuan pemecahan masalah juga dipengaruhi oleh materi pembelajaran yang disajikan. Pembelajaran yang menggunakan masalah dalam kehidupan sehari-hari tentunya menjadi modal untuk memecahkan berbagai masalah yang ada dalam kehidupan nyata. Dengan adanya permasalahan-permasalahan yang dekat dengan kehidupan sehari-hari, maka siswa secara tidak langsung akan menggunakan kecerdasannya untuk memecahkan masalah. Hal ini senada dengan Gadner (Al Maidah et al., 2017) yang menjelaskan bahwa kecerdasan merupakan kemampuan untuk menyelesaikan masalah atau menciptakan produk yang berharga dalam lingkungan budaya dan masyarakat. Lebih lanjut, Gadner mengidentifikasi ada delapan kecerdasan meliputi 1) kecerdasan verbal-linguistik, 2) kecerdasan logis-matematis, 3) kecerdasan visual-spasial, 4) kecerdasan kinestetik, 5) kecerdasan musikal, 6) kecerdasan intrapersonal, 7) kecerdasan interpersonal, dan 8) kecerdasan naturalis. Semua kecerdasan yang dimiliki oleh individu akan bekerjasama menjadi kesatuan yang utuh, meskipun setiap individu memiliki komposisi masing-masing yang berbeda. Kecerdasan yang paling menonjol akan mengontrol kecerdasan lainnya dalam memecahkan masalah, sehingga setiap individu memiliki pemecahan masalah yang berbeda.

Kemampuan pemecahan masalah dapat dimiliki siswa apabila ia memperoleh kesempatan yang sama. Oleh karena itu, media board game dirancang melalui pembelajaran yang memberikan aktivitas bermain untuk dilakukan setiap individu. Media dirancang dengan aturan menyelesaikan kartu soal untuk meraih poin sehingga setiap individu berlomba-lomba untuk menjadi pemenang. Dengan adanya media pembelajaran yang berkaitan dengan aktivitas belajar sambil bermain, siswa akan tertarik dan menumbuhkan minat untuk mengikuti 
pembelajaran. Hal ini sejalan dengan salah satu fungsi media pembelajaran yakni memberi suasana belajar yang menyenangkan, tidak tertekan, santai, dan menarik sehingga dapat mencapai tujuan pembelajaran (Saifuddin, 2014).

\section{SIMPULAN}

Berdasarkan hasil penelitian dan pengembangan, dapat disimpulkan bahwa media board game dapat meningkatkan kemampuan pemecahan masalah layak digunakan dalam pembelajaran. Hal ini ditunjukkan dari hasil validasi pakar media, materi, dan pakar pembelajaran yang terbukti valid. Keefektifan media ditunjukkan dari hasil belajar siswa berdasarkan Paired Sample t-test dengan Sig (2.tailed) sama dengan 0,000 atau kurang dari 0,05, sehingga dapat dikatakan bahwa terdapat perbedaan yang signifikan antara hasil data pre-test dan post-test. Kepraktisan media ditunjukkan dari hasil angket respon siswa setelah menggunakan media board game dalam pembelajaran dengan persentase $94 \%$.

Peneliti memberikan saran kepada beberapa pihak dalam dunia pendidikan. Bagi siswa yang sering melakukan aktivitas bermain diharapkan dapat menambah pengetahuan melalui kegiatan belajar sambil bermain. Bagi guru, agar dapat memilah dan memanfaatkan media pembelajaran yang sesuai dengan karakteristik siswa dan dapat menumbuhkan minat siswa untuk belajar. Bagi kepala sekolah, agar dapat mempertimbangkan pemanfaatan media pembelajaran yang sesuai dengan karakteristik siswa dan tuntutan pendidikan zaman sekarang. Bagi peneliti selanjutnya, diharapkan dapat mengembangkan produk dari penelitian ini yang sesuai dengan perkembangan zaman, serta mempertimbangkan kelayakan, keefektifan, dan kepraktisan media untuk penelitian selanjutnya.

\section{DAFTAR PUSTAKA}

Al Maidah, A., Setyosari, P., \& Kuswandi, D. (2017). Pengembangan bahan ajar tematik cetak semi digital berbasis multiple intelligences untuk siswa kelas I SD. Seminar Nasional Teknologi Pembelajaran Dan Pendidikan Dasar 2017 , 11-16.

Danarti, Dessy. 2010. 52 Fun Family Full Games Mudah, Murah, Menarik, Kreatif, Edukatif, Sekaligus Menyenangkan. Yogyakarta: CV ANDI.

Direktorat Pembinaan Sekolah Dasar. 2017. Materi Pokok SD. Jakarta: Kementrian Pendidikan dan Kebudayaan

Jatisunda, M. G. (2017). Hubungan self-efficacy siswa SMP dengan kemampuan pemecahan masalah matematis. Jurnal THEOREMS (The Original Research of Mathematics), 1(2).

Kustiawan, Usep. 2016. Pengembangan Media Anak Usia Dini. Malang: Gunung Samudera.

Larasati, D. (2018). PENGEMBANGAN MEDIA CHAMPIONSHIP TRACK

Mulyati, T. (2016). Kemampuan pemecahan masalah matematis siswa sekolah dasar. EDUHUMANIORA: Jurnal Pendidikan Dasar, 3(2).

Kemendikbud. (2016). Permendikbud Nomor 22 Tahun 2016 Tentang Standar Proses Pendidikan Dasar Dan Menengah. Kemdikbud.

Kustiawan, U. (2016). Pengembangan Media Anak Usia Dini. Gunung Samudera.

Prastowo, A. (2015). Menyusun Rencana PelaksanaanPembelajaran (RPP) Tematik Terpadu Implementasi Kurikulum 2013 untuk SD/MI. Kencana.

Rusman. (2017). Belajar dan Pembelajaran Berorientasi Standar Proses Pendidikan. Kencana. 
Saifuddin. (2014). Pengelolaan Pembelajaran Teoritis dan Praktis. . Deepublish. Sanjaya, Wina. 2017. Paradigma Baru Mengajar. Jakarta: Kencana.

Saraswati, D., Kristin, F., \& Anugraheni, I. (2018). Peningkatan kemampuan pemecahan masalah matematika menggunakan model Means-ends Analysis (MEA) bagi siswa kelas 5 SD Negeri Sumogawe 02. Jurnal pendidikan dasar perkhasa: Jurnal Penelitian Pendidikan Dasar, 4(1), 1-12.

Soebagio, M. F., Yuwono, E. C., \& Soewito, B. M. (2015). Perancangan Media Permainan Edukatif mengenai Kuliner dari Pemanfaatan Mangrove untuk Anak Usia 8-12 Tahun. Jurnal DKV Adiwarna, 1(6), 13.

Suda, I. K. (2016). Pentingnya Media dalam Meningkatkan Kualitas Pembelajaran Siswa di Sekolah Dasar. Universitas Hindu Indonesia.

Susanto, A. (2016). Teori Belajar dan Pembelajaran di Sekolah Dasar. Prenadamedia Group.

Trianto. 2011. Desain Pengembangan Pembelajaran Tematik Bagi Anak Usia Dini TK/ RA \& Anak Kelas Awal SD/ MI. Jakarta: Kencana Prenada Media Group.

Triastuti, D., \& Irawan, E. B. (2017). Pengembangan Media Papan Permainan Panjat Pinang. Jurnal Pendidikan: Teori, Penelitian, dan Pengembangan, 2(10), 1344-1350.

Trinova, Z. (2012). Hakikat Belajar dan Bermain Menyenangkan bagi Peserta Didik. . Al-Ta Lim Journal, 19(3), 209-215.

Wahyudi, \& Anugraheni, I. (2017). Strategi Pemecahan Masalah Matematika. . Satya Wacana University Press. 